\title{
Dexamethasone increases plasma amino acid concentrations in bronchopulmonary dysplasia
}

\author{
A F Williams, M Jones
}

\begin{abstract}
Nine ventilated low birthweight babies were treated with dexamethasone $(0.6 \mathrm{mg} / \mathrm{kg} / \mathrm{day})$. Appreciable suppression of weight gain was accompanied by uraemia and significant increases in the concentration of all amino acids except phenylalanine, tyrosine, threonine, and glutamate. Ornithine, citrulline, alanine, glutamine, and cystine concentrations increased threefold or more. The findings could not be explained by changes in dietary intake and presumably reflect pronounced catabolism, though the effects of dexamethasone on intermediary metabolism and membrane transport could also play a part.
\end{abstract}

Dexamethasone is used increasingly to treat infants with bronchopulmonary dysplasia, principally to facilitate the withdrawal of mechanical respiratory support. ${ }^{12}$ The precise mode of action of this drug in bronchopulmonary dysplasia is not clear, but lung compliance is known to increase, possibly through clearance of interstitial oedema. Treatment, which may be given for six weeks or more, ${ }^{2}$ is usually accompanied by suppression of weight gain and uraemia, indicating the presence of catabolism. ${ }^{3}$ The metabolic vulnerability of immature infants provided with protein in excess of growth requirements is well known, ${ }^{4-7}$ but there are no data about the metabolic effects of high dose corticosteroid treatment in this group of patients. In this study we have measured the effect of dexamethasone on plasma amino acid concentrations.

\section{Patients and methods} PATIENTS

The infants studied had been mechanically ventilated from birth. Table 1 gives the birth weight and gestational and postnatal age of each. Dexamethasone was used in the presence of radiographic abnormalities suggestive of chronic lung disease when conventional respirator weaning techniques had failed. The decision to treat was taken by the clinician responsible and no other experimental intervention to the standard nursery protocol was made. The dose of dexamethasone employed was 0.6

Department of Child Health, St George's Hospital Medical School, Cranmer Terrace, London SW17 ORE

A F Williams

A Jones

Correspondence to: Dr Williams.

Accepted 13 August 1991
The method of feeding was determined by each infant's clinical state and not regulated for the venously or orally.

\section{FEEDING}

purpose of this study. None of the infants was completely enterally fed and all were receiving commercial parenteral nutrition solutions (Vamin Infant, Kabi Pharmacia, 10\% dextrose $\pm 20 \%$ Intralipid, Kabi Pharmacia), as a part or the whole of their nutrient intake. The parenteral nutrition regimens used in our nursery provide between 167 and $502 \mathrm{~kJ} / \mathrm{kg} /$ day, depending on lipid tolerance, and amino acid intake is adjusted to constrain protein equivalent: energy ratio between 3.35 and $6.70 \mathrm{~g} / \mathrm{MJ}$. Enterally fed infants received low birthweight formula (Cow and Gate) or human milk when available. Total nitrogen and energy intakes were calculated from nursing records and manufacturers' compositional data. The nitrogen content of human milk was assumed to be $200 \mathrm{mg} / 100 \mathrm{ml}$, and the energy content 251 $\mathrm{kJ} / 100 \mathrm{ml}$ or $293 \mathrm{~kJ} / 100 \mathrm{ml}$, depending on whether banked milk (a mixture of dripped and expressed milk) or mother's own milk respectively was used.

\section{ANTHROPOMETRY}

Weight (g) was measured daily when clinical state permitted, using an averaging electronic scale with resolution of $1 \mathrm{~g}$ and precision of \pm 4 g. Weight gain was calculated as the linear regression coefficient (slope) of these measurements on time (days). This was divided by body weight at the commencement of treatment for comparative expression in units of $\mathrm{g} / \mathrm{kg} / \mathrm{day}$. Although such ratio 'correction' can lead to erroneous conclusions when comparison is made between infants of differing size, we made comparison only within subjects between treatment periods.

\section{BIOCHEMICAL ANALYSIS}

Heparinised venous blood samples $(0.5 \mathrm{ml})$ were drawn before the first dose of dexamethasone and on one occasion between two and seven days later when a clinical indication

Table 1 Clinical characteristics of the infants studied

\begin{tabular}{llll}
\hline $\begin{array}{l}\text { Patient } \\
\text { No }\end{array}$ & $\begin{array}{l}\text { Birth weight } \\
(\mathrm{g})\end{array}$ & $\begin{array}{l}\text { Gestation } \\
\text { (weeks) }\end{array}$ & $\begin{array}{l}\text { Postnatal age } \\
\text { (days) }\end{array}$ \\
\hline 1 & 1041 & 29 & 16 \\
2 & 664 & 24 & 32 \\
3 & 2300 & 32 & 13 \\
4 & 842 & 28 & 18 \\
5 & 726 & 24 & 22 \\
6 & 830 & 25 & 45 \\
7 & 1048 & 26 & 31 \\
8 & 918 & 26 & 17 \\
9 & 715 & 27 & 22 \\
Median & 842 & 26 & 22 \\
\hline
\end{tabular}


for routine sampling arose. Plasma was separated immediately and frozen to $-20^{\circ} \mathrm{C}$. A $200 \mu \mathrm{l}$ aliquot was deproteinised with $20 \mu \mathrm{l}$ of $35 \%$ $(w / v)$ sulphosalicylic acid after the addition of $200 \mu \mathrm{l}$ of $250 \mu \mathrm{mol} / \mathrm{l} \mathrm{L}$-norleucine, which was used as an internal standard. The mixture was vortexed for a few seconds before incubating at room temperature for 5 minutes and then centrifuging again for 5 minutes at $15850 \mathrm{~g}$. An aliquot of $350 \mu \mathrm{l}$ of the deproteinised supernatant was mixed with an equal volume of Beckman lithium diluent (ph 2.2) and the sample either stored at $-60^{\circ} \mathrm{C}$ or filtered through a $0.22 \mu \mathrm{m}$ filter for immediate analysis.

Amino acid concentrations were measured using a cation exchange high performance liquid chromatography (HPLC) system (Beckman System Gold) with postcolumn ninhydrin derivatisation, detecting primary amino acids and related compounds at $570 \mathrm{~nm}$ wavelength. The system was calibrated using a 250 $\mu \mathrm{mol} / \mathrm{l}$ Beckman physiological standard. For each infant, specimens collected before and during treatment were analysed sequentially to ensure compatible measurement conditions. The precision (coefficient of variation) of the assay procedure was established by replicate assay $(n=8)$ of the same sample of adult blood. It lay between 1.5 and $5 \cdot 2 \%$ for all amino acids except citrulline $(10 \cdot 7 \%)$.

Plasma urea was determined by the urease method on a random access analyser in the hospital routine laboratory.

\section{STATISTICAL ANALYSIS}

The number of patients studied was small $(n=9)$ and most variables did not appear normally distributed. Consequently the Wilcoxon signed rank test has been employed to make comparisons before and during treatment within infants. Two tailed probability estimates (p) are quoted throughout; values of $<0.05$ were deemed significant.

\section{Results}

NITROGEN AND ENERGY INTAKE DURING STUDY Table 2 shows the average daily nitrogen and energy intake of each baby during the seven days before and the seven days after dexamethasone was commenced. These, and protein:energy ratio, did not differ significantly between the two periods (Wilcoxon signed rank test). There was a small difference in the ratio of

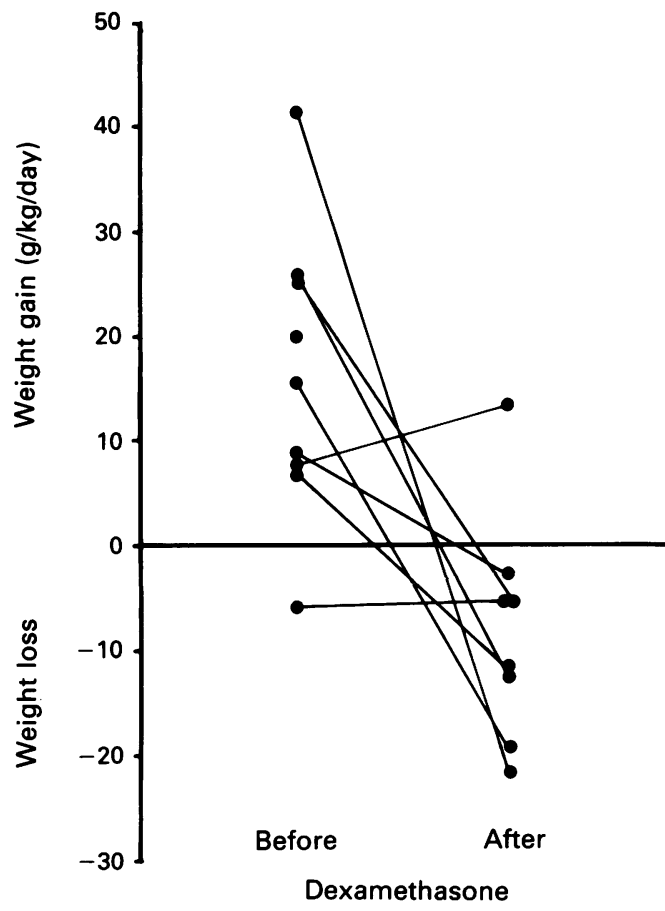

Figure 1 Weight gain (g/kg/day) during the week before commencing dexamethasone and during the first week of treatment.

enteral to parenteral intake between treatment periods: the median proportion of total fluid intake as milk before treatment was $26 \%$ (range $0-91 \%$ ) and $19 \%$ (range $0-66 \%$ ) during treatment. This difference was not significant (Wilcoxon signed rank test, $\mathrm{p}>0 \cdot 1$ ) and was attributable to interruption of enteral feeding on endotracheal extubation.

\section{WEIGHT GAIN}

Figure 1 shows tied values for average daily weight gain or loss during the week before and the week after commencing dexamethasone treatment. In one case insufficient weight data were obtained during the second week to calculate rate of change. In six of the remaining eight cases there was a net weight loss on treatment. These changes were significant (Wilcoxon signed rank test, $\mathrm{p}<0.05$ ).

\section{PLASMA UREA CONCENTRATIONS}

Figure 2 shows the distribution of plasma urea values with time. There was a clear increase in

Table 2 Nitrogen, energy intakes, and weight velocity of infants studied

\begin{tabular}{|c|c|c|c|c|c|c|}
\hline \multirow{2}{*}{$\begin{array}{l}\text { Patient } \\
\text { No }\end{array}$} & \multicolumn{3}{|c|}{ Before dexamethasone } & \multicolumn{3}{|c|}{ After dexamethasone } \\
\hline & $\begin{array}{l}\text { Nitrogen } \\
\text { intake } \\
\text { (mg/kg/day) }\end{array}$ & $\begin{array}{l}\text { Energy } \\
\text { intake } \\
\text { (kf/kg/day) }\end{array}$ & $\begin{array}{l}\text { Weight } \\
\text { velocity } \\
\text { (g/kg/day) }\end{array}$ & $\begin{array}{l}\text { Nitrogen } \\
\text { intake } \\
\text { (mg/kg/day) }\end{array}$ & $\begin{array}{l}\text { Energy } \\
\text { intake } \\
\text { (kf/kg/day) }\end{array}$ & $\begin{array}{l}\text { Weight } \\
\text { velocity } \\
\text { (g/kg/day) }\end{array}$ \\
\hline $\begin{array}{l}1 \\
2 \\
3 \\
4 \\
5 \\
6 \\
7 \\
8 \\
9\end{array}$ & $\begin{array}{l}246 \\
350 \\
107 \\
326 \\
356 \\
392 \\
293 \\
287 \\
289\end{array}$ & $\begin{array}{l}368 \\
439 \\
205 \\
477 \\
418 \\
435 \\
330 \\
318 \\
405\end{array}$ & $\begin{array}{r}-5 \cdot 8 \\
6.9 \\
20.0 \\
41.3 \\
26.0 \\
25.4 \\
8.8 \\
15.7 \\
7.7\end{array}$ & $\begin{array}{r}324 \\
36 \\
98 \\
236 \\
259 \\
363 \\
449 \\
410 \\
330\end{array}$ & $\begin{array}{l}431 \\
401 \\
134 \\
397 \\
380 \\
380 \\
531 \\
414 \\
410\end{array}$ & $\begin{array}{r}-5 \cdot 2 \\
-11 \cdot 7 \\
{ }^{*} \\
-21 \cdot 2 \\
-5 \cdot 3 \\
-12 \cdot 3 \\
-2 \cdot 8 \\
-19 \cdot 1 \\
13 \cdot 4\end{array}$ \\
\hline Median & 293 & 405 & $15 \cdot 7$ & 330 & 401 & $-8 \cdot 5$ \\
\hline
\end{tabular}

"Denotes insufficient data to calculate velocity. 


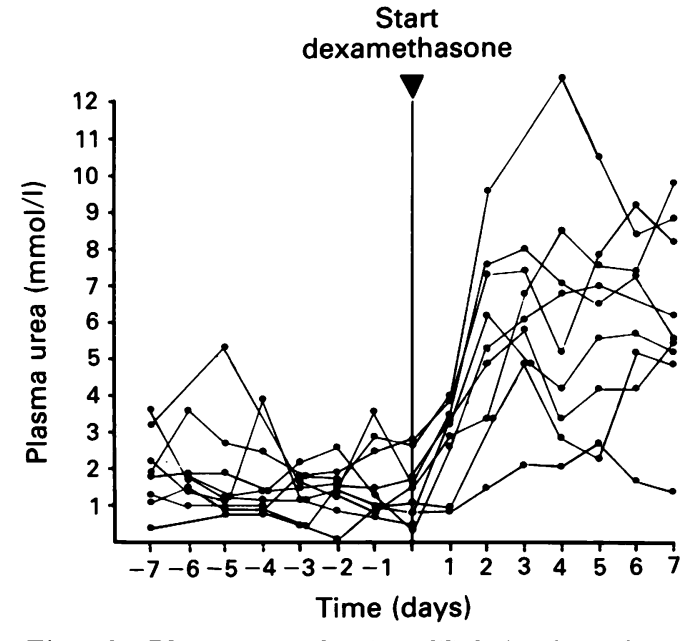

Figure 2 Plasma urea values ( $m m o l / l)$ during the week before commencing dexamethasone and during the first week of treatment.

both the median plasma urea concentration and variability between individuals during treatment.

PLASMA AMINO ACID CONCENTRATIONS

Table 3 shows the median concentration (with range) for each amino acid before and after treatment. Significant increases were observed in all except glutamic acid, threonine, phenylalanine, and tyrosine concentrations (Wilcoxon signed rank test; $p$ values given in table 3 ). The uniformity of the changes across infants was striking; in the case of most of the amino acids an increase was observed in every infant studied, notable exceptions being threonine, glutamic acid, phenylalanine, and tyrosine. The most appreciable increases were noted in ornithine, citrulline, cystine, methionine, glutamine, and alanine concentrations (fig 3 ).

\section{Discussion}

Dexamethasone treatment was associated with suppression of weight gain and striking increases in the plasma concentrations of most amino acids and urea. These changes could not be attributed to differences in nitrogen and energy intake between treatment periods. Our assumptions about the composition of human milk are unlikely to have influenced comparative nutrient intakes. This is firstly because the quantities employed were small and, secondly, because only within subject, between period comparisons were made. The small, statistically non-significant changes in the disposition of nutrient intake between parenteral and enteral routes are also unlikely to have been important, particularly as the protein:energy ratio was constrained during parenteral nutrition. Moreover, the pattern of hyperaminoacidaemia we describe differs from that previously observed by Räihä et al in dietary protein excess. ${ }^{4-7}$ Concentrations of alanine, glycine, ornithine, lysine, histidine, serine, and threonine measured during dexamethasone treatment in our study were greater than those observed by Räihä et al in low birthweight infants fed unadjusted cows' milk protein at $4 \cdot 5 \mathrm{~g} / \mathrm{kg} / \mathrm{day}$. Conversely, the concentrations of leucine, isoleucine, valine, phenylalanine, tyrosine, citrulline, glutamate, and
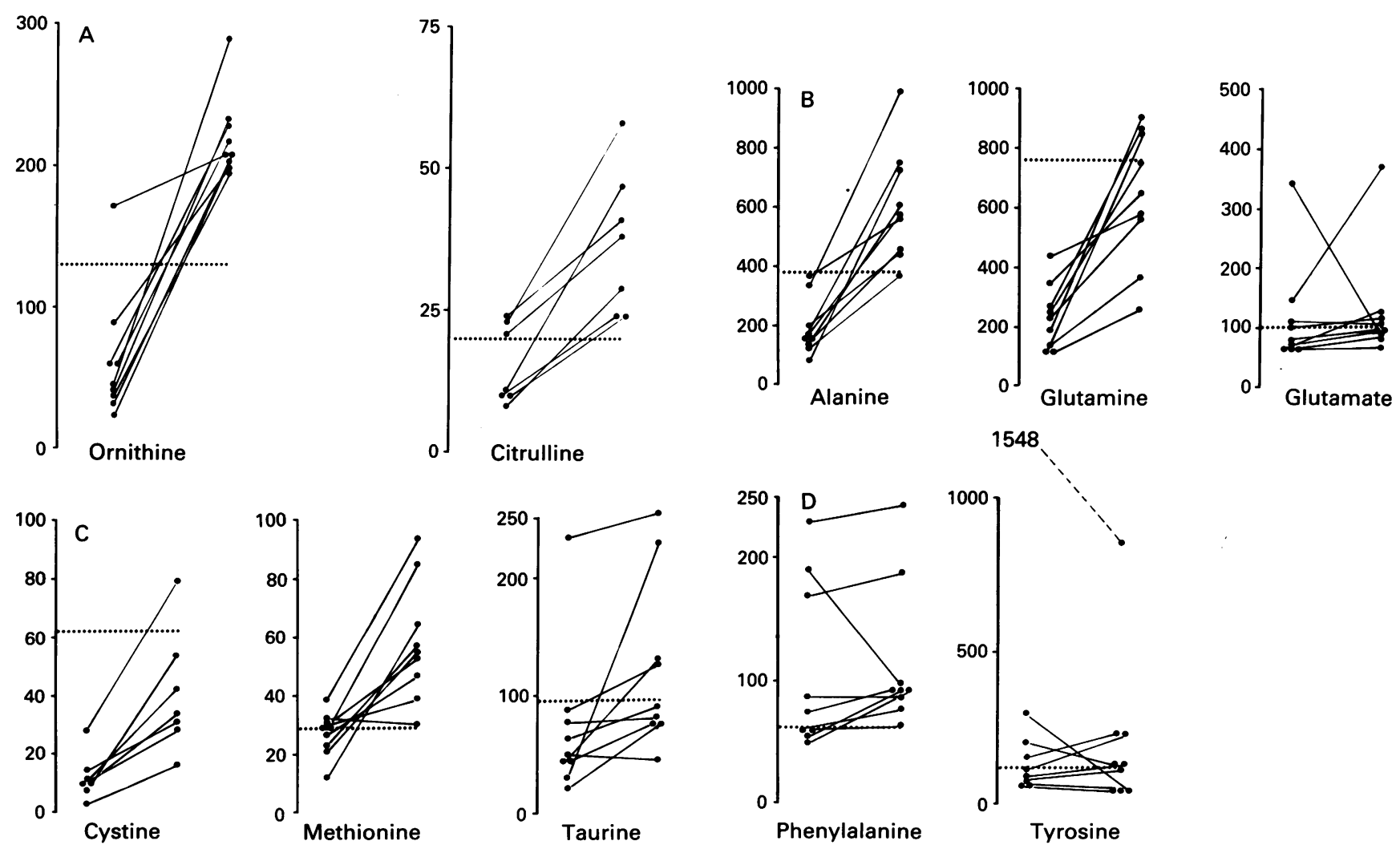

Figure 3(A-D) Plasma amino acid concentrations in umolll. Values for samples taken before and after commencing dexamethasone are tied for individual infants. Dotted line indicates 90 th centile value for ad libitum term breast fed infants. ${ }^{18}$ 
Table 3 Concentrations of plasma amino acids before and after treatment

\begin{tabular}{|c|c|c|c|c|}
\hline & $\begin{array}{l}\text { Median concentration } \\
(\mu \text { molll) before } \\
\text { treatment (range) }\end{array}$ & $\begin{array}{l}\text { Median concentration } \\
(\mu \text { molll) after } \\
\text { treatment (range) }\end{array}$ & $p$ Value & $\begin{array}{l}\text { Median concentration } \\
(\mu m o l / l) \text { for breast } \\
\text { fed term infants } \\
(10 \text { th, } 90 \text { th centile })\end{array}$ \\
\hline $\begin{array}{l}\text { Ornithine } \\
\text { Citrulline } \\
\text { Cystine } \\
\text { Taurine } \\
\text { Methionine } \\
\text { Alanine } \\
\text { Asparagine } \\
\text { Glutamine } \\
\text { Glutamic acid } \\
\text { Glycine } \\
\text { Serine } \\
\text { Threonine } \\
\text { Lysine } \\
\text { Histidine } \\
\text { Leucine } \\
\text { Valine } \\
\text { Isoleucine } \\
\text { Proline } \\
\text { Phenylalanine } \\
\text { Tyrosine }\end{array}$ & $\begin{array}{c}45(24-171) \\
11(8-24) \\
11(3-28) \\
48(22-236) \\
29(12-39) \\
161(83-362) \\
35(8-96) \\
228(114-440) \\
76(64-341) \\
295(123-509) \\
191(86-316) \\
176(60-430) \\
127(43-278) \\
74(39-218) \\
94(67-164) \\
176(120-274) \\
40(14-80) \\
150(84-586) \\
75(53-230) \\
115(62-1548)\end{array}$ & $\begin{array}{c}207(195-287) \\
34(16-58) \\
34(16-79) \\
89(46-256) \\
55(30-94) \\
572(371-992) \\
87(58-120) \\
651(258-902) \\
96(68-368) \\
558(388-1007) \\
415(213-599) \\
260(188-491) \\
280(194-410) \\
136(114-260) \\
154(103-170) \\
265(143-391) \\
59(32-99) \\
281(170-708) \\
94(66-239) \\
130(44-853)\end{array}$ & $\begin{array}{l}<0.001 \\
<0.001 \\
<0.001 \\
<0.001 \\
<0.001 \\
<0.001 \\
<0.001 \\
<0.001 \\
\text { NS } \\
<0.001 \\
<0.001 \\
\text { NS } \\
<0.001 \\
<0.001 \\
<0.002 \\
<0.001 \\
<0.05 \\
<0.001 \\
\text { NS } \\
\text { NS }\end{array}$ & $\begin{array}{r}84(49,116) \\
13(6,20) \\
52(34,62) \\
50(27,96) \\
20(13,29) \\
235(163,387) \\
53(43,87) \\
610(468,755) \\
56(36,98) \\
183(120,228) \\
109(80,143) \\
104(76,134) \\
148(92,210) \\
66(44,85) \\
103(73,160) \\
153(108,184) \\
49(32,71) \\
212(162,283) \\
41(23,63) \\
72(45,117)\end{array}$ \\
\hline
\end{tabular}

cystine which we measured were lower, and those of methionine, proline, glutamine, and taurine similar to those described by Räihä et al. The low cystine concentration measured in our study is particularly noteworthy and probably reflects the relatively high requirement for parenteral nutrition and low intake of human milk.

It seems unlikely that the plasma amino acid concentrations attained were intrinsically harmful as none approached levels characteristic of metabolic disease. Indeed, neonatal tyrosinaemia observed in one infant of 24 weeks' gestation improved after 48 hours of dexamethasone treatment, perhaps as a result of tyrosine aminotransferase induction. ${ }^{8}$ The complexity of the metabolic response to steroid treatment makes it difficult, however, to be certain of the mechanisms underlying the changes that we have observed. The most important is likely to be a change in the balance between rate of protein synthesis and breakdown, but corticosteroid induced changes in active transport of amino acids across membranes could also affect cellular uptake. For example, corticosteroids reduce amino acid uptake by skeletal muscle and lymphoid tissue but increase uptake by hepatocytes. ${ }^{9}$ The effects of corticosteroids on intracellular metabolism appear similarly complex-for example, hydrocortisone treatment both increased carbamoyl phosphate synthetase-I activity and decreased ornithine transcarbamoylase activity in fetal rat liver. ${ }^{10} \mathrm{It}$ is not clear to what extent the changes we observed in the urea cycle intermediates ornithine and citrulline were due to an overall increase in protein oxidation or to what extent any inhibition of ornithine transcarbamoylase might have been responsible.

Although the changes induced by glucocorticoids are often described as 'catabolic', protein turnover studies have suggested that nitrogen wasting results both from a decrease in protein synthesis and a rise in degradation rates, ${ }^{11} 12$ though the latter may fall in some tissues. ${ }^{12}$ Skeletal muscle has been considered to show the most appreciable effects. In the rat, those muscles with the highest proportion of fast fibres (for example, extensor digitorum longus) show the most noticeable atrophy and reduction in protein synthesis, whereas those with a greater proportion of slow fibres (for example, soleus) tend to be spared. The diaphragm, which contains a mixture of fast and slow fibres, appears to behave in an intermediate manner. ${ }^{12} 13$ At present, there are no data on the effect of corticosteroids on diaphragmatic structure and function in the immature human infant.

The effect of corticosteroids on skeletal muscle has also been extensively studied in mature dogs. Muhlbacher et al showed a significant efflux of glutamine from skeletal muscle in animals given $0.44 \mathrm{mg} / \mathrm{kg} /$ day of dexamethasone. ${ }^{14}$ However, the changes which they observed in plasma amino acid concentrations differ from those which we have noted in immature infants. Most notably, ornithine, glutamine, and cystine concentrations fell while alanine increased by a factor of only 1.5 . In contrast, rats treated with $6 \mathrm{mg} / \mathrm{kg} / \mathrm{day}$ of dexamethasone showed a rise in plasma glutamine concentration accompanied by efflux of glutamine and alanine from the lung. ${ }^{15}$ This is of interest because the human and the rat, unlike the dog and other species studied, appear to release glutamine from the lung. ${ }^{15}$ A recent observation that dexamethasone treatment appreciably suppresses lung growth and protein synthesis in the adolescent rat $^{16}$ raises the possibility that the increased plasma alanine and glutamine concentrations we describe here could be attributable as much to suppression of protein synthesis in the lung as in skeletal muscle. By analogy with the effects of dietary protein restriction in the rat this might be expected to increase lung compliance ${ }^{17}$ and produce short term clinical improvement, but also to slow the rate of repair.

In summary, we observed striking increases in the plasma concentrations of most amino acids in immature infants treated with dexamethasone. These changes may reflect suppression of protein synthesis in both the lung and the respiratory musculature, but the relative contributions of effects of membrane transport and intermediary metabolism remain to be determined. 
1 Mammel MC, Green TP, Johnson DE, Thompson TR. Controlled trial of dexamethasone therapy in infants with bontrolled trial of dexamethasone therapy in infan

2 Cummings JJ, D'Eugenio DB, Gross SJ. A controlled trial of dexamethasone in preterm infants at high risk for bronchodexamethasone in preterm infants at high risk for bronch

3 MacDonald PD, Galea P, Alroomi LG. A catabolic state in dexamethasone treatment of bronchopulmonary dysplasia. Arch Dis Child 1990;65:560-1.

4 Räihä NCR, Heinonen K, Rassin DK, Gaull GE. Milk protein quantity and quality in low birthweight infants: I. metabolic responses and effects on growth. Pediatrics 1976;57:659-74.

5 Rassin DK, Gaull GE, Heinonen K, Räihä NCR. Milk protein quantity and quality in low birthweight infants: II effects on selected aliphatic amino acids in plasma and urine. Pediatrics 1977;59:407-22

6 Gaull GE, Rassin DK, Räihä NCR, Heinonen K. Milk protein quantity and quality in low birthweight infants: III. effects on sulfur amino acids in plasma and urine 7 Pediat 1977;90:348-55.

7 Rassin DK, Gaull GE, Räihä NCR, Heinonen K. Milk protein quantity and quality in low birthweight infants: IV effects on tyrosine and phenylalanine in plasma and urine. effects on tyrosine and phe
$\mathcal{J}$ Pediatr 1977;90:356-60.

8 Rosen F, Harding HR, Milholland RJ, Nichol CA. Glucocorticoids and transaminase activity. F Biol Chem 1963;238: corticoids a $3725-9$.

9 Christensen HN, Kilberg MS. Amino acid transport across the plasma membrane: role of regulation in interorgan flows. In: Yudelivich DL, ed. Amino acid transport in animal cells. Manchester: Manchester University Press, 1987:10-46.

10 Gautier C, Habechi Z, Belbekouche M, Vaillant R Effect of corticosteroids and pancreatic hormones on carbamoyl Vaillant R. Effect of fynthetase I and ornithine transcarbamoylase

11 Goldberg AL, Tischler M, deMartino G, Griffin G. Hormonal regulation of protein degradation and synthesis in skeletal muscle. Federation Proceedings 1980;39:31-6.

12 Kelly FJ, McGrath JA, Goldspink DF, Cullen MJ. A morphological/biochemical study on the actions of corticosteroids on rat skeletal muscle. Muscle Nerve 1986;9:1-10.

13 Steiss JE, Wright JC, Cox NR. Effects of perinatal high dose dexamethasone on skeletal muscle development in rats. Can F Vet Res 1989;53:17-22.

14 Muhlbacher F, Kapadia CR, Colpoys MF, Smith RJ, Wilmore DW. Effects of glucocorticoids on glutamine metabolism in skeletal muscle. Am $\mathcal{F}$ Physiol 1984;247: metabol

15 Souba WW, Plumley DA, Salloum RM, Copeland EM. Effects of glucocorticoids on lung glutamine and alanine metabolism. Surgery 1990;108:213-9.

16 Fussell JC, Kelly FJ. Effects of dexamethasone on lung protein turnover. Biochem $\mathcal{F}$ 1991;273:93-7.

17 Matsui R, Thurlbeck WM, Fujita Y, Yu SY, Kida K. Connective tissue, mechanical and morphometric changes in the lungs of weanling rats fed a low protein diet. Pediatr Pulmonol 1989;7:159-66.

18 Pohlandt F. Plasma amino acid concentrations in newborn infants breast-fed ad libitum. $\mathcal{F}$ Pediatr 1978;92:614-6. 